\title{
An unusual case of meningitis
}

\author{
Eric DR Pond BSc ${ }^{1}$, Sameh El-Bailey MbChb DCP FRCPath ${ }^{1,2}$, Duncan Webster MA MD FRCPC ${ }^{3}$
}

\section{EDR Pond, S El-Bailey, D Webster. An unusual case of meningitis. Can J Infect Dis Med Microbiol 2015;26(3):e62-64.}

Pasteurella multocida is a rare cause of bacterial meningitis. A 56-yearold man with several pets developed a profoundly decreased level of consciousness following left tympanomastoidectomy. Lumbar puncture produced cerebrospinal fluid with the typical findings of meningitis (low glucose, high protein, high leukocytes). Cultures from the cerebrospinal fluid and a swab of the left ear revealed Gram-negative coccobacillus identified as $P$ multocida. The organism was sensitive to ceftriaxone, ampicillin and penicillin, and a 14-day course of intravenous penicillin was used as definitive treatment, resulting in full recovery. Although rare, $P$ multocida should be considered as a potential cause of meningitis in patients with animal exposure, particularly in the setting of recent cranial surgery.

Key Words: Pasteurella multocida; Meningitis; Tympanomoastoidectomy; Zoonosis

\section{Un cas inhabituel de méningite}

Le Pasteurella multocida est une rare cause de méningite bactérienne. Un homme de 56 ans propriétaire de plusieurs animaux a présenté une importante diminution de son niveau de conscience après une tympanomastoïdectomie gauche. Le liquide céphalorachidien prélevé par ponction lombaire présentait les caractéristiques classiques de la méningite (glycémie basse, protéine élevée, leucocytes élevés). Les cultures du liquide céphalorachidien et un écouvillon de l'oreille gauche ont révélé un coccobacille à Gram négatif, le $P$ multocida. L'organisme était sensible à la ceftriaxone, à l'ampicilline et à la pénicilline. Un traitement de pénicilline administré par voie intraveineuse pendant 14 jours a favorisé un rétablissement complet. Même si c'est rare, le P multocida doit être envisagé comme cause de méningite chez des patients exposés à des animaux, particulièrement après avoir subi une opération crânienne.

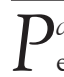
asteurella multocida is a Gram-negative coccobacillus. It is a small, encapsulated, nonmotile facultative anaerobe, commonly found as part of the commensal oral flora in animals. Carriage rates among domestic animals, such as cats and dogs, have been shown to be as high as $70 \%$ to $90 \%$ and $55 \%$, respectively $(1,2)$, and it is also carried by a variety of other domestic and wild animals (3). It is, therefore, an important zoonotic organism. $P$ multocida has been reported to cause a variety of infections in humans including cellulitis, subcutaneous abscesses, septic arthritis, osteomyelitis, bacteremia, endocarditis, meningitis, and various oral and respiratory tract infections; however, skin manifestations are by far the most common (3).

The present article describes a rare case of $P$ multocida meningitis in a patient following tympanomastoidectomy.

\section{CASE PRESENTATION}

A 56-year-old man developed chronic otorrhea related to left tympanic membrane perforation. He was admitted for an elective left typanomastoidectomy and removal of the incus and malleus with tympanoplasty. His medical history included hypertension, dyslipidemia, gout, polycystic kidney disease and gastroesophageal reflux disease. His surgical history was significant for previous left tympanoplasty and inguinal hernia repair. His medications at the time of admission were rosuvastatin, domperidone, esomeprazole, allopurinol, irbesartan/hydrochlorothiazide and labetalol.

On the first day postoperatively the patient experienced a sudden drop in his level of consciousness accompanied by marked agitation, and required intubation. His Glasgow Coma Scale score was 9 (eyes 3 , verbal 3, motor 3). There were no focal neurological signs, his pupils were symmetrical but sluggish to react and the fundi appeared normal. His blood glucose level was $9.0 \mathrm{mmol} / \mathrm{L}$. He was subsequently transferred to the intensive care unit. A computed tomography scan of the patient's head showed no structural abnormalities, no masses and no hematoma. Lumbar puncture was performed and revealed cloudy cerebrospinal fluid (CSF) with an elevated protein level $(5.78 \mathrm{~g} / \mathrm{L})$, low glucose level $(<1.0 \mathrm{mmol} / \mathrm{L})$ and a leukocyte count of $11,974 \times 10^{6} / \mathrm{L}$, with $95 \%$ neutrophils. Based on these findings, the patient was treated empirically for bacterial meningitis with intravenous (IV) vancomycin, ceftriaxone and dexamethasone pending culture results and sensitivities. Further blood work revealed a blood leukocyte count of $13.8 \times 10^{9} / \mathrm{L}$, hemoglobin level of $123 \mathrm{~g} / \mathrm{L}$ and platelet count of $154 \times 10^{9} / \mathrm{L}$. His serum sodium level was $146 \mathrm{mmol} / \mathrm{L}$, potassium level $3.6 \mathrm{mmol} / \mathrm{L}$, chloride level $106 \mathrm{mmol} / \mathrm{L}$, urea level $12.6 \mathrm{mmol} / \mathrm{L}$ and creatinine level $190 \mu \mathrm{mol} / \mathrm{L}$.

Initial Gram stain of the CSF using the cytospin technique revealed abundant polymorphonuclear leukocytes and no organisms. Preliminary reports revealed growth of Gram-negative coccobacilli, and at this point metronidazole was also added to the treatment regime until an anaerobic cause was ruled out. Ultimately, the organism was identified from aerobic cultures as P multocida using the Vitek 2 identification system (bioMérieux, USA). Anaerobic cultures were negative. The isolate was sensitive to ceftriaxone, ampicillin and penicillin. Interestingly, a swab of the left ear performed on postoperative day 2 grew the same organism as that cultured from the CSF (growth on chocolate and blood agar; no growth on MacConkey's or inhibitory mold agar). The empirical antibiotics and dexamethasone were discontinued, and the patient was started on a 14-day course of IV penicillin G at a dose of 2,000,000 units every $4 \mathrm{~h}$. The patient made a rapid recovery from his meningitis, and he was discharged on postoperative day 10 to continue treatment as an outpatient. On further questioning, it was revealed that the patient was the primary caregiver of several pet cats and a dog, although he reported no history of bites. The pets were allowed on the furniture, including his bed, and would occasionally lick his face.

\footnotetext{
${ }^{1}$ Dalhousie University; ${ }^{2}$ Microbiology, Saint John Regional Hospital; ${ }^{3}$ Internal Medicine/Medical Microbiology, Dalhousie University Correspondence: Eric Pond, Medical Education 3 South, 400 University Avenue, Saint John, New Brunswick E2L 4L2. Telephone 506-333-4967, e-mailer513463@dal.ca
} 
TABLE 1

A list of cases of Pasteurella multocida meningitis published in the English literature after 1999

\begin{tabular}{|c|c|c|c|c|c|c|}
\hline \multicolumn{7}{|c|}{ Author (reference), Age, years } \\
\hline year & (sex) & Predisposing factors & Animal exposure & Clinical findings & Treatment (duration) & Outcome \\
\hline $\begin{array}{l}\text { Brossier et al (13), } \\
2010\end{array}$ & $46(F)$ & $\begin{array}{l}\text { Transethmoidal pituitary } \\
\text { adenectomy }\end{array}$ & Contact with cats & $\begin{array}{l}\text { Headache; fever; nuchal } \\
\text { rigidity; epistaxis }\end{array}$ & $\begin{array}{l}\text { Cefotaxime and } \\
\text { ofloxacin (1 week) }\end{array}$ & Recovered \\
\hline $\begin{array}{l}\text { Kawashima et al (15), } \\
2010\end{array}$ & $44(F)$ & None & Kissing her dog & $\begin{array}{l}\text { Headache; fever; nausea; } \\
\text { neck stiffness }\end{array}$ & Meropenem (1 week) & Recovered \\
\hline Tjen et al (17), 2007 & $44(F)$ & Otitis media & $\begin{array}{l}\text { Face licked by } \\
\text { pet dog }\end{array}$ & $\begin{array}{l}\text { Headache; vomiting; fever; } \\
\text { drowsy; neck stiffness; } \\
\text { right-sided paralysis }\end{array}$ & Chloramphenicol & Recovered \\
\hline $\begin{array}{l}\text { Tattevin et al (18), } \\
2005\end{array}$ & $60(F)$ & Chronic mastoiditis & Cat bite & $\begin{array}{l}\text { Fever; chills; rigors; } \\
\text { nuchal rigidity; agitation; } \\
\text { decreased responsiveness }\end{array}$ & Benzylpenicillin (2 weeks) & Recovered \\
\hline $\begin{array}{l}\text { O'Neill et al (20), } \\
2005\end{array}$ & $72(F)$ & None & Pet cat & $\begin{array}{l}\text { Fever; jaundice; decreased } \\
\text { level of consciousness; } \\
\text { neck stiffness }\end{array}$ & $\begin{array}{l}\text { Cefatoxime cefotaxime } \\
\text { (14 days), penicillin } \\
\text { (27 days) }\end{array}$ & $\begin{array}{l}\text { Obstructive hydrocephalus } \\
\text { requiring shunt and } \\
\text { eventual recovery }\end{array}$ \\
\hline $\begin{array}{l}\text { Proulx et al (21), } \\
2003\end{array}$ & $33(F)$ & None & Dog scratch & $\begin{array}{l}\text { Headache; neck pain; photo- } \\
\text { phobia; fever; tachycardia }\end{array}$ & Penicillin (14 days) & Recovered \\
\hline $\begin{array}{l}\text { Armstrong et al (22), } \\
2000\end{array}$ & $52(\mathrm{M})$ & None & $\begin{array}{l}\text { Pet dog, animal } \\
\text { feces indoors }\end{array}$ & Found dead at home & - & Death \\
\hline
\end{tabular}

F Female; M Male

\section{DISCUSSION}

Meningitis is an uncommon outcome of $P$ multocida infection (3), making $P$ multocida a rare cause of adult bacterial meningitis. Two reviews spanning 1950 to 1999 report only 29 cases published in the English literature during that time period $(4,5)$. Animal contact was a major risk factor, present in $89 \%$ of cases, and a history of a bite was much less common, occurring only $15 \%$ of the time (4). Previous cranial/facial surgery or skull fracture has been reported as a cause of $P$ multocida meningitis (5-13). Table 1 summarizes adult cases of $P$ multocida meningitis published in the English literature after 1999 (13-22). Animal contact was present in all cases, while only two (20\%) reported a history of a bite. One patient had a history of cranial surgery (13).

The current report presents one of only a handful of cases of $P$ multocida meningitis ever documented in the literature from a Canadian site $(5,6,9,21,23)$. The patient developed a severely decreased level of consciousness after tympanomastoidectomy. The patient had the typical CSF findings of bacterial meningitis (low glucose, high protein, high leukocytes). Penicillin is the most commonly used antibiotic to treat $P$ multocida meningitis $(4,15)$, and our patient recovered fully with a course of IV penicillin G. Many of the more recent cases describe treating with third generation cephalosporins (Table 1).

$P$ multocida meningitis has been reported following mastoidectomy $(11,12)$, and the pathogenesis of infection is hypothesized to involve contiguous spread of the organism from a colonized ear canal. Supporting this theory, a swab of our patient's ear canal grew $P$ multocida. Our patient had experienced chronic otorrhea. Local spread from an adjacent infected site has been proposed as an etiology (4) because chronic otitis media and otorrhea have been found in association with $P$ multocida meningitis $(4,19,24-27)$. Our patient showed no signs of clinical meningitis preoperatively; therefore, extension to the surgical site is the likely mechanism in this case. A preoperative ear swab has been proposed for patients having a mastoidectomy that have a history of exposure to animals (12), and may be supported by the present case.
ACKNOWLEDGEMENTS: The authors acknowledge the hard work and contribution of the technical staff of the Microbiology Division at the Saint John Regional Hospital (Saint John, New Brunswick).

\section{REFERENCES}

1. Owen CR, Buker EO, Bell JF, Jellison WL. Pasteurella multocida in animal mouths. Rocky Mountain Med J 1968;65:45-6.

2. Smith JE. Studies on Pasteurella septica. I. The occurrence in the nose and tonsils of dogs. J Comp Pathol Ther 1955;65:239-45.

3. Weber DJ, Wolfson JS, Swartz MN, Hooper DC. Pasteurella multocida infections. Report of 34 cases and review of the literature. Medicine (Baltimore) 1984;63:133-54.

4. Green BT, Ramsey KM, Nolan PE. Pasteurella multocida meningitis: Case report and review of last $11 \mathrm{y}$. Scand J Infect Dis 2002;34:213-74.

5. Kumar A, Devlin HR, Vellend H. Pasteurella multocida meningitis in an adult: Case report and a review. Rev Infect Dis 1990;12:440-8.

6. Goodman Y. Human Pasteurella multocida infections in Alberta. Can J Med Technol 1960;22:104-9.

7. Permezel JM, Smith CC, Flint E, Young HA. Opportunistic Pasteurella multocida meningitis. J Laryngol Otol 1984;98:939-40.

8. Roberts SR, Esther JW, Brewer JH. Post-traumatic Pasteurella multocida meningitis. South Med J 1988;81:675-6.

9. Dolman PJ, Ezzat S, Rootman J, Bowie WR. Pasteurella multocida meningitis following orbital exenteration. Am J Ophthalmol 1988;105:698-9.

10. Casolari C, Fabio U. Isolation of Pasteurella multocida from human clinical specimens: First report in Italy. Eur J Epidemiol 1988;4:389-90.

11. Parry CM, Cheesbrough JS, O'Sullivan G. Meningitis due to Pasteurella multocida. Rev Infect Dis 1991;13:187.

12. Dammeijer PF, McCombe AW. Meningitis from canine Pasteurella multocida following mastoidectomy. J Laryngol Otol 1991;105:571-2.

13. Brossier F, Clemenceau S, Lecso-Bornet M, Jarlier V, Sougakoff W. Two concomitant but unrelated cases of Pasteurella multocida infection, including meningitis secondary to pituitary adenoma microsurgery. Med Mal Infect 2010;40:590-2. 
14. López C, Sanchez-Rubio P, Betrán A, Terré R. Pasteurella multocida bacterial meningitis caused by contact with pigs. Braz J Microbiol 2013:44:473-4.

15. Kawashima S, Matsukawa N, Ueki Y, Hattori M, Ojika K. Pasteurella multocida meningitis caused by kissing animals: A case report and review of the literature. J Neurol 2010;257:653-4.

16. Per H, Kumandaş S, Gümüş H, Oztürk MK, Coşkun A. Meningitis and subgaleal, subdural, epidural empyema due to Pasteurella multocida. J Emerg Med 2010;39:35-8.

17. Tjen C, Wyllie SA, Pinto A. Pasteurella meningo-encephalitis a risk of household pets. J Infect 2007;55:479-80.

18. Tattevin P, Souala F, Gautier AL, et al. Diabetes in patients with pasteurellosis. Scand J Infect Dis 2005;37:731-3.

19. Jordan EF, Nye MB, Luque AE. Successful treatment of Pasteurella multocida meningitis with aztreonam. Scand J Infect Dis 2007;39:72-4.

20. O'Neill E, Moloney A, Hickey M. Pasteurella multocida meningitis: Case report and review of the literature. J Infect 2005;50:344-5.
21. Proulx NL, Freedman MS, Chan JW, Toye B, Code CC. Acute disseminated encephalomyelitis associated with Pasteurella multocida meningitis. Can J Neurol Sci 2003;30:155-8.

22. Armstrong GR, Sen RA, Wilkinson J. Pasteurella multocida meningitis in an adult: Case report. J Clin Pathol 2000;53:234-5.

23. Burdge DR, Scheifele D, Speert DP. Serious Pasteurella multocida infections from lion and tiger bites. JAMA 1985;253:3296-7.

24. McCue JD. Pasteurella multocida meningitis. J Maine Med Assoc 1979;70:461-2.

25. Smith FR. Pasteurella multocida meningitis. Postgrad Med J 1980;56:250-1.

26. Bruun B, Friis-Moller A. Meningitis and bacteremia caused by Pasteurella multocida. A case report. Acta Pathol Microbiol Immunol Scand 1983;91:329-331.

27. Godey B, Morandi X, Bourdiniere J, Heurtin C. Beware of dog licking ears. Lancet 1999;354:1267-8. 


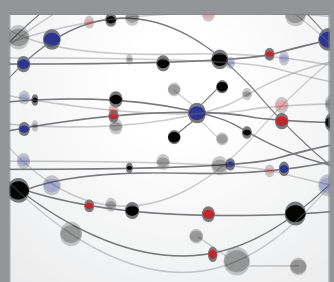

The Scientific World Journal
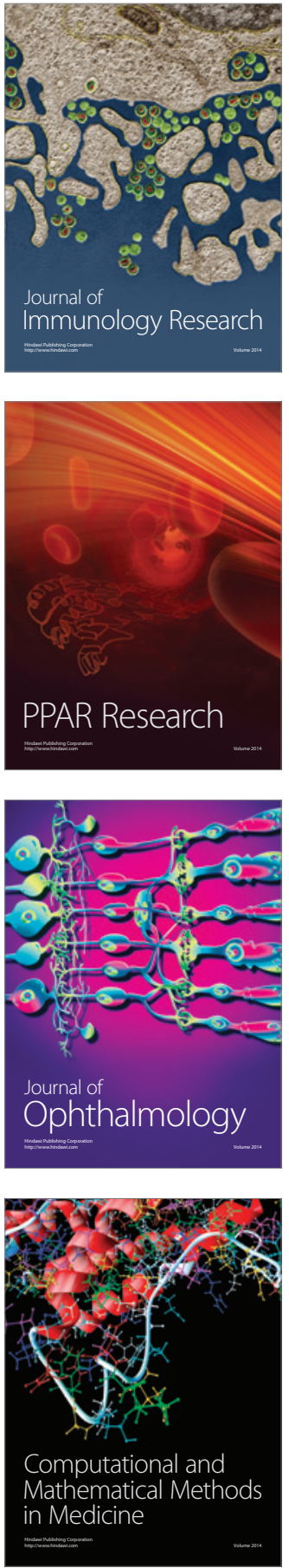

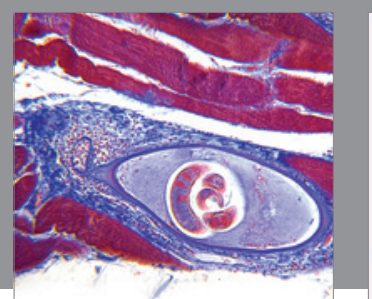

Gastroenterology Research and Practice

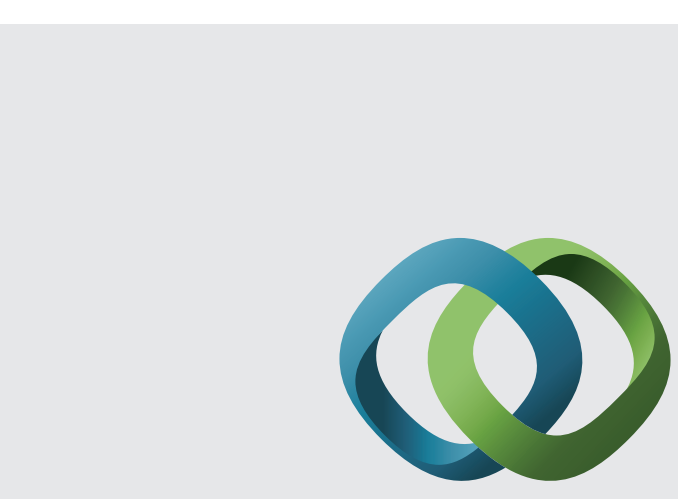

\section{Hindawi}

Submit your manuscripts at

http://www.hindawi.com
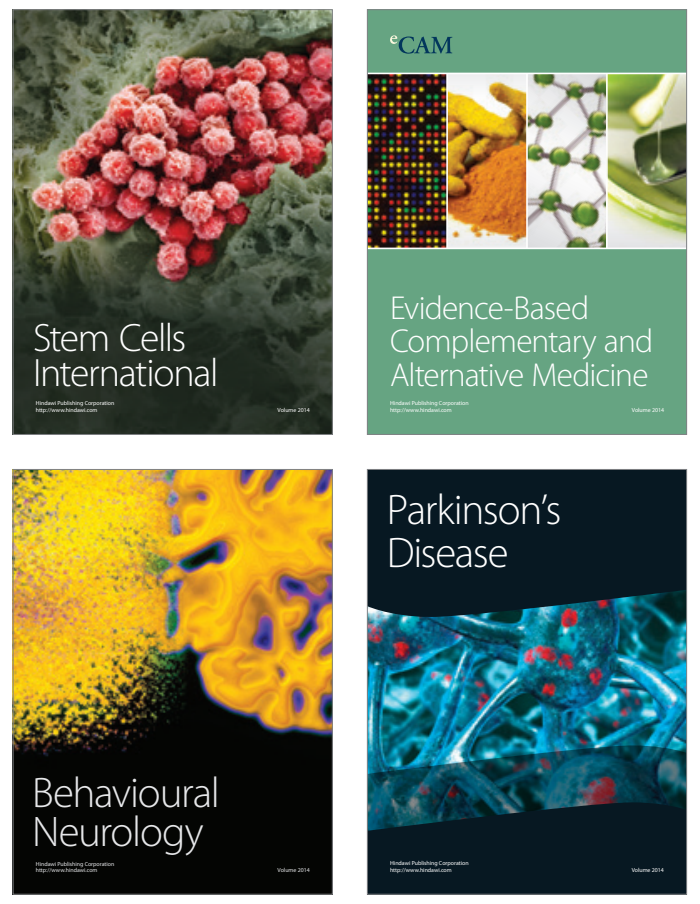
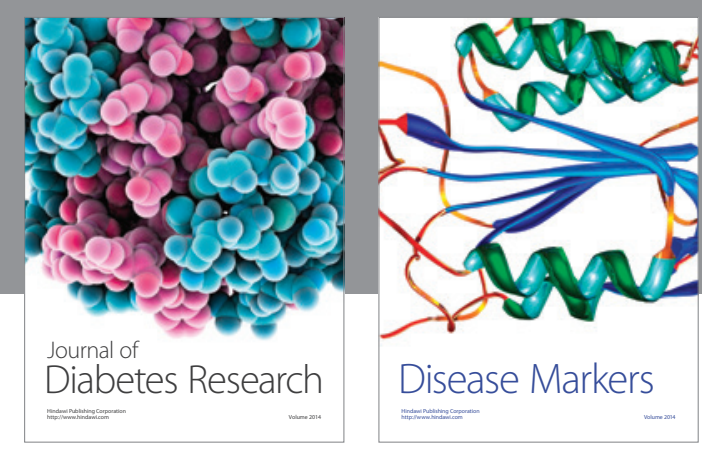

Disease Markers
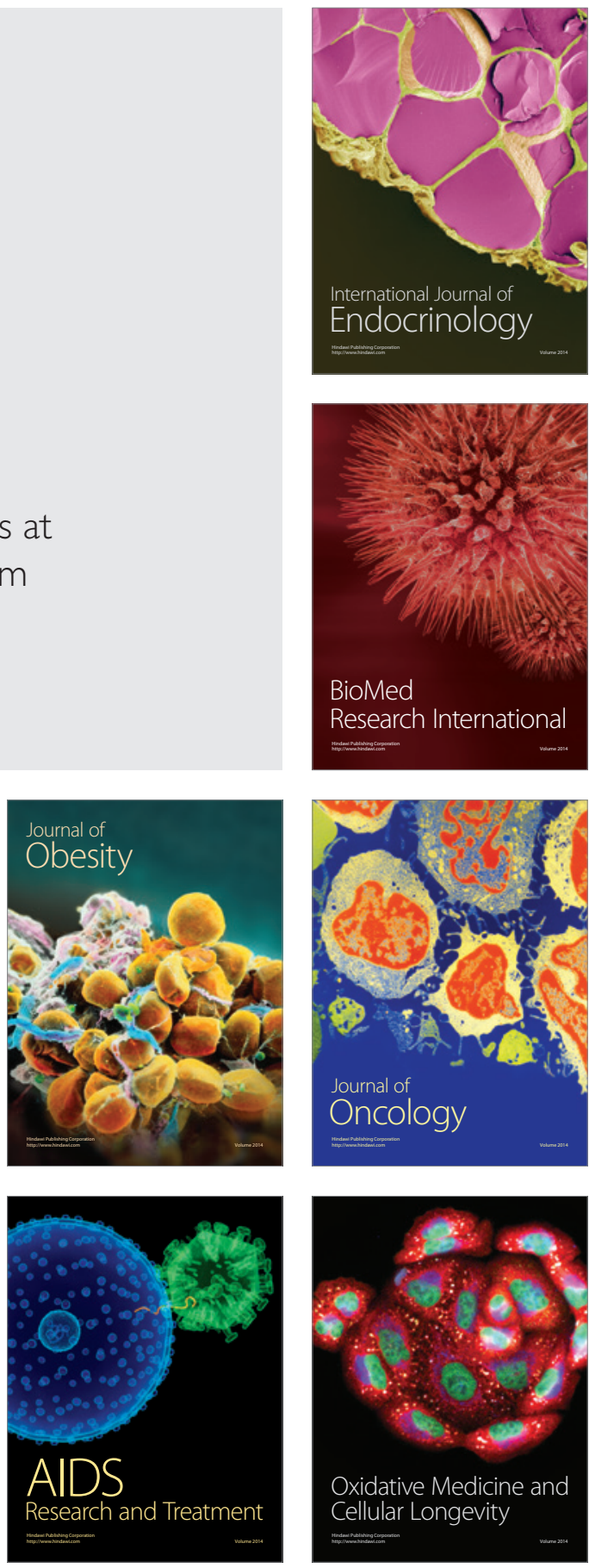